\title{
HUBUNGAN TINGKAT KECEMASAN DENGAN MORBUS HANSEN \\ DAN FAKTOR - FAKTOR YANG MEMPENGARUHINYA DI BAGIAN \\ KULIT DAN KELAMIN BLU RSUP PROF. DR. R. D. KANDOU \\ MANADO PERIODE NOVEMBER - DESEMBER 2012
}

\author{
${ }^{1}$ Shinta Purnama Hardy \\ ${ }^{2}$ Anita E. Dundu \\ ${ }^{3}$ Theresia M. D. Kaunang
}

\author{
Kandidat Skripsi Fakultas Kedokteran Universitas Sam Ratulangi ${ }^{1}$, \\ Bagian Psikiatri Fakultas Kedokteran Universitas Sam Ratulangi \\ Manado². \\ Email : shipha085@gmail.com
}

\begin{abstract}
Relationship between Anxiety Level and Morbus Hansen and the Influencing Factors in Dermatologic Division Prof. Dr. R. D. Kandou General Hospital Manado period of November - December 2012. Introduction : anxiety is defined as a emotional tension that often accompained by physical, sweating, increase of pulse rate. Morbus Hansen (hanseniasis), or well known as leprosy, is a chronic infectious disease caused by Mycobacterium Leprae. In Indonesia leprosy are endemic disease, the number of leprosy patients estimated to be greater than that recorded in the health department, because of the high leprofobi and stigma againstleprosy. Method : this study is analytical, with a cross sectional approach. Result : based of the chi square test the results are no significant association $(p>0,05)$ between anxiety and age, sex, education, and employment. Conclusion : There is no significant association between anxiety and Morbus Hansen.
\end{abstract}

Keyword: Anxiety, HRS-A, Leprosy.

\begin{abstract}
Abstrak : Hubungan tingkat kecemasan dengan morbus hansen dan faktor - faktor yang mempengaruhinya di Bagian Kulit dan Kelamin BLU RSUP Prof. DR. R. D. Kandou Manado periode November - Desember 2012. Pendahulan : kecemasan didefinisikansebagai suatu keadaan ketegangan emosional yang sering disertai dengan gejala fisik, seperti ketegangan, tremor, palpitasi, berkeringat dan peningkatan denyut nadi. Penyakit Morbus Hansen (hanseniasis), atau yang lebih dikenal dengan penyakit lepra atau kusta, merupakan penyakit infeksi kronis yang disebabkan oleh Mycobacterium Leprae. Di Indonesia penyakit
\end{abstract}


kusta bersifat endemis, jumlah penyakit kusta diperkirakan lebih besar daripada yang tercatat di Departemen Kesehatan, karena adanya leprofobi dan stigma yang tinggi terhadap kusta.

Metode : penelitian ini bersifat analitik, dengan pendekatan cross sectional. Hasil : berdasarkan hasil uji chi square di dapatkan tidak ada hubungan yang bermakna ( $p>0,05)$ antara kecemasan dengan umur, jenis kelamin, pendidikan dan pekerjaan. Kesimpulan : Tidak ada hubungan yang bermakna antara kecemasan dengan Morbus Hansen.

Kata kunci: HRS-A, Kecemasan, Kusta.

Kecemasan merupakan salah satu emosi yang paling banyak dirasakan oleh setiap individu dengan tingkat yang berbeda-beda. Perasaan tersebut dapat mengganggu kegiatan sehari-hari seseorang bila sudah sampai pada tingkat yang sedang atau berat. ${ }^{1}$

Kecemasan adalah responss terhadap suatu ancaman yang sumbernya tidak diketahui, internal, samar-samar atau konfliktual. Kecemasan dibagi menjadi tiga macam yaitu kecemasan realistik, kecemasan moral dan kecemasan neurotik. Kecamasan ini dibagai menurut asal datangnya perasaan cemas tersebut. ${ }^{2}$

Dalam teori Behavior dijelaskan bahwa kecemasan muncul melalui clasical conditioning, artinya seseorang mengembangkan reaksi kecemasan terhadap hal-hal yang telah pernah dialami sebelumnya dan reaksi-reaksi yang telah dipelajari dari pengalamannya sebelumnya, Sebagai contoh, pada seorang anak kecil yang telah mendapat hukuman karena berbohong, jadi ketika anak tersebut melakukan suatu kebohongan lagi akan timbul kecemasan pada dirinya karena takut akan di hukum. ${ }^{3}$

Kecemasan yang menurut kamus lengkap psikologi disebut sebagai anxiety ini, digambarkan sebagai suatu perasaan takut yang tidak menyenangkan. Perasaan takut yang tidak menyenangkan ini akan memengaruhi pola pikir sehingga akan timbul perasaan bahkan pikiran yang negatif. Pikiran yang negatif ini pun akan memengaruhi aktivitas atau pekerjaan sehari-hari dan akibatnya akan sangat mengganggu hasil dari pekerjaan itu sendiri. $^{4}$ Penyakit Morbus Hansen (hanseniasis), atau yang lebih dikenal dengan penyakit lepra atau kusta, merupakan penyakit infeksi kronis yang disebabkan oleh Mycobacterium Leprae. Di Indonesia penyakit kusta bersifat endemis, jumlah penderitanya diperkirakan lebih besar dari yang tercatat di Departemen Kesehatan, karena adanya leprofobi dan stigma yang tinggi terhadap kusta. Hal ini disebabkan oleh kecacatan yang ditimbulkan, yaitu deformitas dan mutilasi, sehingga terjadi ketakutan. Ketakutan akibat kurangnya pemahaman dan tersedianya informasi tepat dan akurat mengenai penyakit kusta. Stigma dan masalah psikososial dapat berperan dalam timbulnya gangguan jiwa pada pasien, dan akhirnya dapat menimbulkan komorbiditas pada penderita kusta. ${ }^{5}$

Morbus Hansen yang biasa dikenal dengan lepra atau kusta adalah sebuah penyakit infeksi kronis yang disebabkan oleh bakteri Mycobacterium leprae. Penyakit kusta disebut juga Morbus Hansen, sesuai dengan nama yang menemukan kuman tersebut yaitu Dr. Gerhard Armauwer Hansen pada tahun 1874 sehingga penyakit ini disebut Morbus Hansen. ${ }^{6}$ Penyakit ini adalah tipe penyakit granulamatosa pada saraf tepi dan mukosa dari saluran pernapasan atas, dan lesi pada kulit adalah tanda yang bisa diamati dari luar. Bila tidak ditangani, kusta dapat sangat progresif, menyebabkan kerusakan pada kulit, sarafsaraf, anggota gerak, dan mata. ${ }^{7}$ 
Morbus Hansen sampai saat ini masih ditakuti masyarakat, keluarga termasuk sebagian petugas kesehatan. Hal ini disebabkan masih kurangnya pengetahuan, kepercayaan yang keliru terhadap kusta dan cacat yang ditimbulkannya. ${ }^{8}$

Pada tahun 1995, World Health Organization (WHO) memperkirakan terdapat dua hingga tiga juta jiwa cacat permanen karena kusta. Walaupun pengisolasian atau pemisahan penderita dengan masyarakat tidak etis, beberapa kelompok penderita masih dapat ditemukan di berbagai belahan dunia, seperti India dan Vietnam. ${ }^{9}$

Saat ini sering ditemukan kasus kusta terutama di negara-negara yang sedang berkembang. Menurut data WHO tahun 2007, Indonesia menempati urutan ke-3 dari 10 negara yang terbanyak dalam penemuan kasus baru kusta. Kurangnya informasi tentang penyakit kusta mengakibatkan stigma negatif terhadap penderita kusta sehingga penderita kusta dikucilkan dalam kehidupan bermasyarakat. ${ }^{10}$

Penyakit kusta dapat menimbulkan berbagai masalah seperti masalah terhadap diri penderita kusta, masalah terhadap keluarga penderita, masalah terhadap masyarakat, dan masalah terhadap bangsa dan negara. Hal-hal tersebut dilihat dari segi aspek psiko-sosial dimana penyakit ini selalu disertai stigma dan ketakutan. ${ }^{9}$

Berdasarkan latar belakang diatas, maka penulis merasa tertarik untuk mengambil judul tentang gambaran kecemasan pada penderita Morbus Hansen (lepra).

\section{METODE PENELITIAN}

Penelitian ini bersifat analitik, dengan pendekatan cross sectional. Penelitian ini dilakukan di Poliklinik Bagian Kulit dan Kelamin BLU RSUP.PROF.DR.R.D.KANDOU

MANADO selama bulan November 2012 sampai Desember 2012. Populasi pada penelitian ini adalah semua pasien Morbus
Hansen yang datang ke Poliklinik Bagian Kulit dan Kelamin BLU RSUP. PROF.R.D.KANDOU MANADO. Sampel penelitian adalah pasien Morbus Hansen yang datang ke Poliklinik di Bagian Kulit dan Kelamin RSUP.PROF.DR.R.D.KANDOU

MANADO periode November sampai Desember 2012 yang memenuhi kriteria inklusi dan ekslusi.

Kriteria Inklusi pada penelitian ini adalah 1)Semua pasien yang telah didiagnosa positif Morbus Hansen; 2) Pasien Morbus Hansen yang datang ke Poliklinik bagian Kulit dan Kelamin RSUP.PROF.R.D.Kandou , Manado; 3) Pasien Morbus Hansen yang memiliki minimal 5 lesi pada tipe PBPasien Morbus Hansen yang bersedia menjadi sampel. Kriteria Eksklusi adalah 1) Pasien yang masih suspek Morbus Hansen; 2)Pasien Morbus Hansen yang menjadi pasien rawat inap; 3) Pasien yang datang ke Poliklinik bagian Kulit dan Kelamin RSUP.PROF.R.D.Kandou , Manado dengan keluhan atau penyakit lain.

Variable penelitian pada penelitian ini adalah jenis kelamin, umur, pekerjaan, tingkat pendidikan dan skor HRS-A. Instrument penelitian yang digunakan adalah Informed Consent dan kuesioner HRS-A. Data yang telah dikumpulkan selanjutnya diolah dan dianalisis dengan menggunakan SPSS 17.0.

\section{HASIL PENELITIAN}

\begin{tabular}{|c|c|c|c|c|}
\hline \multicolumn{2}{|c|}{ Variabel } & Kecemasa & $\mathrm{X} 2$ & $\mathrm{P}$ \\
\hline Umur & & & $\begin{array}{l}0,185 \\
3\end{array}$ & 0,356 \\
\hline $15 \leq$ & $\begin{array}{l}\text { Tidak } \\
\text { ada } \\
\text { Ringan } \\
\text { Sedang } \\
\text { Berat } \\
\end{array}$ & $\begin{array}{l}0(0,0 \%) \\
0(0,0 \%) \\
0(0,0 \%) \\
0(0,0 \%)\end{array}$ & & \\
\hline $15-50$ & $\begin{array}{l}\text { Tidak } \\
\text { ada } \\
\text { Ringan } \\
\text { Sedang }\end{array}$ & $\begin{array}{l}0(0,0 \%) \\
0(0,0 \%) \\
7(2,8 \%) \\
12(4,8 \%)\end{array}$ & & \\
\hline
\end{tabular}




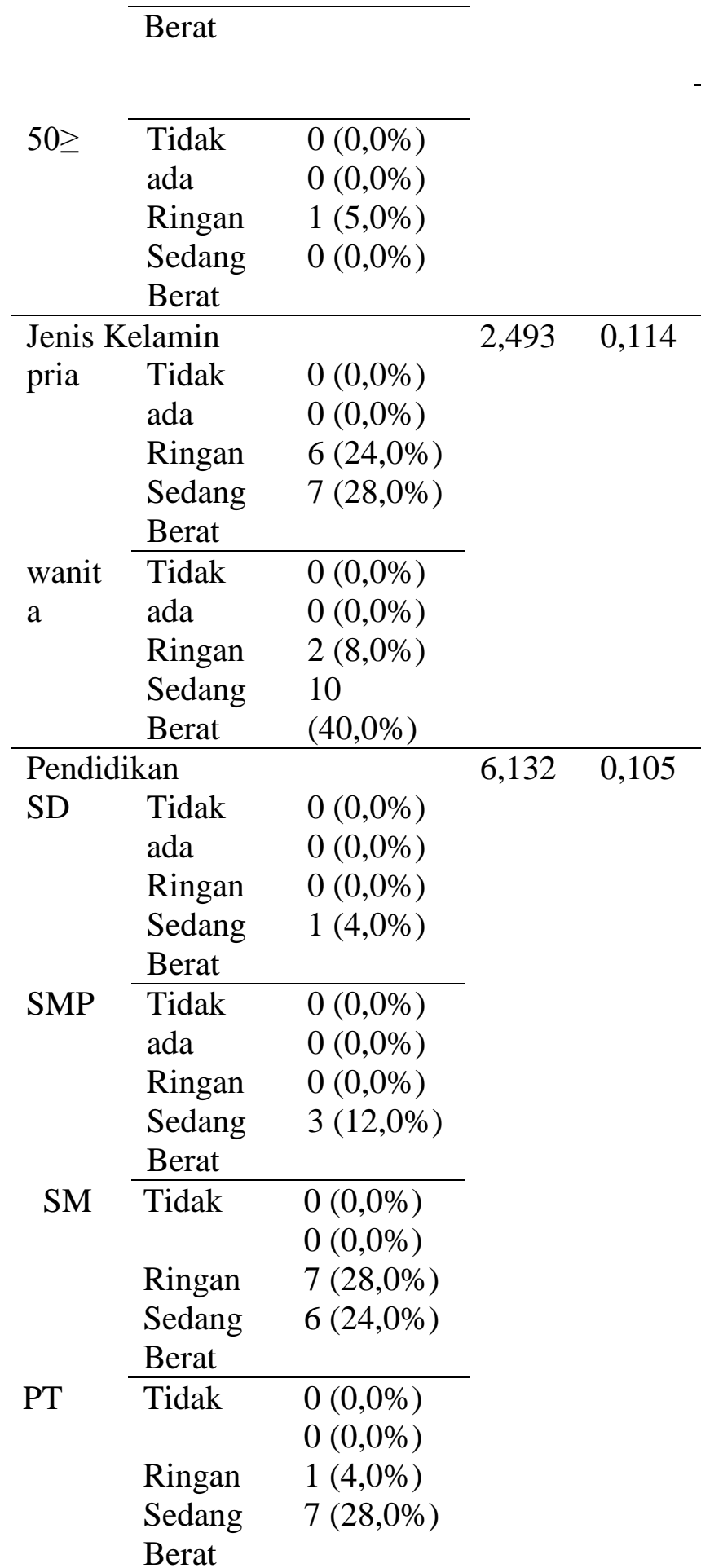

\section{Sedang $\quad 7(28,0 \%)$ \\ Berat \\ Tabel 1. Hasil analisis univariat dan bivariat tingkat kecemasan dengan MH}

Responden terbanyak yang mengalami kecemasan berat sebanyak 17 orang (68\%). Kecemasan sedang dialami sebanyak 8 orang $(32 \%)$. nilai kategori umur $\mathrm{x}^{2}$ hitung $=0,853$ dengan $\mathrm{p}=0,356$. Nilai $\mathrm{x}^{2}$ tabel $=0,00393$ pada derajat kebebasan $(\mathrm{dk})=1$. Hal ini berarti ada hubungan yang tidak signifikan antara kategori umur pasien $\mathrm{MH}$ dengan tingkat kecemasan karena meskipun nilai $x^{2}$ hitung $>\mathrm{x}^{2}$ tabel namun nilai $\mathrm{p}<0,05$.

Responsden terbanyak yang mengalami kecemasan berat sebanyak 10 orang $(40 \%)$ berjenis kelamin perempuan. Kecemasan sedang dialami paling banyak oleh jenis kelamin laki - laki sebanyak 6 orang $(24 \%)$. Nilai jenis kelamin $\mathrm{x}^{2}$ hitung $=2,493$ dengan $p=0,114$. Nilai $x^{2}$ tabel $=$ 0,00393 pada derajat kebebasan $(\mathrm{dk})=1$. Dapat diinterpretasikan bahwa ada hubungan antara jenis kelamin pasien $\mathrm{MH}$ dengan tingkat kecemasan yang tidak signifikan karena nilai $\mathrm{x}^{2}$ hitung $>\mathrm{x}^{2}$ tabel, namun nilai $\mathrm{p}>0,05$.

Responden yang paling banyak mengalami kecemasan memiliki tingkat pendidikan setingkat Sekolah Menengah Atas (SMA) sebanyak 13 orang (52,2\%). Tingkat kecemasan sedang paling banyak dialami oleh responden dengan tingkat pendidikan SMA sebanyak 7 orang $(28,0 \%)$ dan kecemasan berat paling banyak dialami oleh responden dengan tingkat pendidikan PT sebanyak 7 orang $(28,0 \%)$. Nilai pendidikan formal $\mathrm{x}^{2}$ hitung $=6,440$ dengan $\mathrm{p}=0,695$. Nilai $\mathrm{x}^{2}$ tabel $=$

Pekerjaan

\begin{tabular}{lll} 
Kerja & Tidak & $0(0,0 \%)$ \\
& & $0(0,0 \%)$ \\
& Ringan & $5(20,0 \%)$ \\
Sedang & 10 \\
Berat & \\
\hline
\end{tabular}

Tida Tidak $\quad 0(0,0 \%)$

$0(0,0 \%)$

Ringan $3(12,0 \%)$
$0,310 \quad 0,8613,325$ pada derajat kebebasan $(\mathrm{dk})=3$. Dapat diartikan bahwa ada hubungan antara tingkat pendidikan formal pasien MH dengan tingkat kecemasan yang tidak signifikan karena meskipun nilai $\mathrm{x}^{2}$ hitung $>\mathrm{x}^{2}$ tabel, namun nilai $\mathrm{p}>0,05$.

Responden yang paling banyak mengalami tingkat kecemasan sedang adalah yang bekerja sebanyak 5 orang $(20,0 \%)$. Responden yang mengalami 
tingkat kecemasan berat adalah responden yang bekerja sebanyak 10 orang $(40,0 \%)$ responden. Nilai status pekerjaan $\mathrm{x}^{2}$ hitung $=0,031$ dengan $\mathrm{p}=0,861$. Nilai $\mathrm{x}^{2}$ tabel $=$ 0,00393 pada derajat kebebasan $(\mathrm{dk})=1$. Hal ini berarti ada hubungan antara status pekerjaan pasien $\mathrm{MH}$ dengan tingkat kecemasan yang tidak signifikan, karena meskipun $\mathrm{x}^{2}$ hitung $>\mathrm{x}^{2}$ tabel, namun nilai $\mathrm{p}>0,05$.

\section{PEMBAHASAN}

\section{Hubungan umur pasien MH dan tingkat kecemasan}

Kategori terbanyak yang mengalami kecemasan sedang dan berat adalah kategori umur muda dan dewasa (15-50 tahun) masing - masing sebanyak 7 orang $(28,0 \%)$ dan 12 orang $(48,0 \%)$. Berdasarkan pada tabel, nilai kategori umur $\mathrm{x}^{2}$ hitung $=0,853$ dengan $\mathrm{p}=0,356$. Nilai $\mathrm{x}^{2}$ tabel $=0,00393$ pada derajat kebebasan $(\mathrm{dk})=1$. Hal ini berarti ada hubungan yang tidak signifikan antara kategori umur pasien $\mathrm{MH}$ dengan tingkat kecemasan karena meskipun nilai $\mathrm{x}^{2}$ hitung $>\mathrm{x}^{2}$ tabel namun nilai $\mathrm{p}<0,05$.

Hal ini sejalan dengan penelitian yang dilakukan di RSUD Tugurejo Semarang pada tahun 2009 yang menyatakan tidak ada hubungan yang signifikan antara umur dengan tingkat kecemasan. ${ }^{11}$ Namun, hasil penelitian ini tidak sejalan dengan penelitian yang dilakukan di RS Kusta Kediri yang menyatakan adanya hubungan antara tingkat kecemasan penderita kusta dengan umur. ${ }^{10}$

\section{Hubungan Jenis Kelamin dengan Tingkat Kecemasan}

Kategori terbanyak yang mengalami kecemasan sedang berjenis kelamin laki laki sebanyak 6 orang (24\%) dan kategori terbanyak yang mengalami kecemasan berat berjenis kelamin perempuan sebanyak 10 orang $(40,0 \%)$. Berdasarkan nilai pada tabel, jenis kelamin $\mathrm{x}^{2}$ hitung $=$ 2,493 dengan $\mathrm{p}=0,114$. Nilai $\mathrm{x}^{2}$ tabel $=$
0,00393 pada derajat kebebasan $(\mathrm{dk})=1$. Dapat diinterpretasikan bahwa ada hubungan antara jenis kelamin pasien $\mathrm{MH}$ dengan tingkat kecemasan yang tidak signifikan karena nilai $\mathrm{x}^{2}$ hitung $>\mathrm{x}^{2}$ tabel, namun nilai $\mathrm{p}>0,05$. Hal ini sejalan dengan penelitian yang dilakukan di RSUD Tugurejo Semarang pada tahun 2009 yang menyatakan tidak ada hubungan yang signifikan antara jenis kelamin dengan tingkat kecemasan pada pasien kusta. ${ }^{11}$

Namun hal ini bertentangan dengan hasil penelitian yang dilakukan di RS Kusta Kediri yang menyatakan adanya hubungan yang signifikan antara tingkat kecemasan penderita kusta dalam menghadapi pengobatan penyakit dengan jenis kelamin penderita. ${ }^{10}$

\section{Hubungan Pendidikan dengan Tingkat Kecemasan}

Kategori terbanyak yang mengalami kecemasan sedang adalah kategori pendidikan SMA sebanyak 7 orang $(28,0 \%)$ dan kategori terbanyak yang mengalami kecemasan berat adalah kategori pendidikan Perguruan Tinggi sebanyak 7 orang $(28,0 \%)$. Berdasarkan pada tabel, nilai pendidikan formal $\mathrm{x}^{2}$ hitung $=6,440$ dengan $p=0,695$. Nilai $x^{2}$ tabel $=3,325$ pada derajat kebebasan $(\mathrm{dk})$ $=3$. Dapat diartikan bahwa ada hubungan antara tingkat pendidikan formal pasien MH dengan tingkat kecemasan yang tidak signifikan karena meskipun nilai $\mathrm{x}^{2}$ hitung $>x^{2}$ tabel, namun nilai $\mathrm{p}>0,05$.

Hal ini sejalan dengan penelitian yang dilakukan di RSUD Tugurejo Semarang pada tahun 2009 yang menyatakan tidak ada hubungan yang signifikan antara jenis kelamin dengan tingkat kecemasan pada pasien kusta. ${ }^{11}$ Hasil penelitan ini pun sejalan dengan pernyataan yang dikemukakan Priyono yang dikutip dari Nilamsari (2002), yang menyatakan bahwa tingkat pendidikan yang tinggi akan memperluas pandangan dan ruang lingkup pergaulan, sehingga tingkat pendidikan yang lebih tinggi akan 
mempermudah responden untuk menerima informasi tentang kesehatan dan dapat menurunkan tingkat kecemasan dibandingkan dengan yang berperdidikan sedang dan rendah. ${ }^{12}$

Namun hal ini bertentangan dengan hasil penelitian yang dilakukan di RS Kusta Kediri yang menyatakan adanya hubungan yang signifikan antara tingkat kecemasan penderita kusta dalam menghadapi pengobatan penyakit dengan jenis kelamin penderita. ${ }^{10}$

\section{Hubungan Status Pekerjaan dengan Tingkat Kecemasan}

Kategori terbanyak yang mengalami kecemasan sedang dan berat adalah kategori dengan status pekerjaan bekerja masing - masing sebanyak 5 orang $(20,0 \%)$ dan 10 orang $(40,0 \%)$. Berdasarkan pada tabel, nilai status pekerjaan $\mathrm{x}^{2}$ hitung $=0,031$ dengan $\mathrm{p}=$ 0,861 . Nilai $\mathrm{x}^{2}$ tabel $=0,00393$ pada derajat kebebasan $(\mathrm{dk})=1$.

Hal ini berarti ada hubungan antara status pekerjaan pasien $\mathrm{MH}$ dengan tingkat kecemasan yang tidak signifikan, karena meskipun $\mathrm{x}^{2}$ hitung $>\mathrm{x}^{2}$ tabel, namun nilai $\mathrm{p}>0,05$. Hal ini sejalan dengan hasil penelitian yang di lakukan oleh Wandini meggenai faktor - faktor Bedah Sentral RSUD Kraton Pekalongan yang menyatakan adanya hubungan antara status pekerjaan dengan tingkat kecemasan. ${ }^{13}$ Menurut Hellen dan kawan - kawan tahun 1998 mayoritas pasien mengatakan bahwa mereka merasa khawaitr dan mengalami perubahan perilaku yang berhubungan dengan keluarga, sahabat dan pekerjaan mereka serta diri mereka sendiri saat didiagnosis lepra. ${ }^{14}$

\section{SIMPULAN}

Tidak ada hubungan yang bermakna antara tingkat kecemasan dengan Morbus Hansen.

\section{UCAPAN TERIMA KASIH}

Penulis menyadari bahwa penyusunan artikel ini tidak lepas dari bantuan dan bimbingan dari dosen pembimbing. Oleh karena itu, penulis mengucapkan terima kasih kepada dr. Anita E. Dundu, Sp.KJ dan DR. dr. Theresia M. D. Kaunang, Sp.KJ(K) selaku dosen pembimbing. Penulis juga berterima kasih kepada semua pihak yang secara langsung maupun tidak langsung membantu menumbuhkan ide dalam penulisan artikel ini.

\section{DAFTAR PUSTAKA}

1. Atkinson RL, Atkinson RC, Smith EE, Bem DJ. Hilgard's Psychology. $13^{\text {th }}$ edition. New York: Harcourt College Publisher; 2002.

2. Kaplan, saddok. Sinopsis Psikiatri. Jilid 2. Jakarta: Binarupa Aksara; 1997.

3. Bellack AS, Hersen M. Behavioral Asessment,A Practicalo Handbook: Third Edition. New York: Pergamon Press; 1988.

4. Neale JM, Davidson GC. Abnormal Psychology. New York: John Willey \& Sons, Inc.; 2001.

5. Gambaran Gangguan Jiwa pada Penderita Kusta Di Poliklinik Kulit dan Kelamin RSUPN Dr. Cipto Mangunkusumo Periode Januari 2008 April 2008. Medical Riset Unit FK-UI 2008; 2008

6. Kusta. Scribd (Internet). 2007 Feb 24 (cited 2012 Sept 8). Available from://www.scribd.com.

7. Zulkifli. Penyakit Kusta dan Masalah yang Ditimbulkannya. Sumatera Utara: USU Digital Library; 2003.

8. Depkes RI. Morbus Hansen. 2006.

9. Depkes RI. Penanganan Sistim Koping. 1990.

10. Aji B. Faktor yang Berhubungan Dengan Tingkat Kecemasan Penderita Kusta Dalam Menghadapi Pengobatan Penyakit Kusta di Rumah Sakit Kusta Kediri. Library of Public Health Faculty Airlangga Unversity; 2012.

11. Trisnaning R. Hubungan Karakteristik, Tingkat Pengetahuan dengan Tingkat Kecemasan Pasien Pasca Didiagnosa 
Kusta di Poli Kusta RSUD Tugurejo

Semarang. Semarang: UNIMUS

Digital Library; 2012.

12. Nilam Sari D. Minat Wanita Melakukan Mammography Ditinjau Dari Tingkat Pendidikan. Kusuma W. Kedaruratan Psikiatri dalam Praktek. Jakarta: Profesional Book; 1997.

13. Al- okali M, El-Shourbagy, Wassif. Psychiatric Morbidity (Depression and Anxiety) In Children With Some Dermatological Diseases At Derna, Libya. Zagzig Journal Of Occupation Health and Safety. 2008;1:60-70.

14. Kumar A, Anbalogan M. Socioeconomic Experience of Leprosy Patients. 1983. Dalam: Kar S, Kar GC, Pati T, Ratih NM, Swain SP. Study of Social Functioning in Leprosy Patients. Orissa Journal Psychiatry. 2009: 31-4.Lahey B, Ciminero A. Maladaptive Behaviour :An Introduction to Abnormal Psychology. 1980;192-195. 